\title{
EEF2K Gene
}

National Cancer Institute

\section{Source}

National Cancer Institute. EEF2K Gene. NCI Thesaurus. Code C119726.

This gene is involved in both protein phosphorylation and the inhibition of translation. 